\title{
Genetic selection? A study of individual variation in the enzymes of folate metabolism
}

Barbara A Jennings ${ }^{1 *}{ }^{*}$, Gavin A Willis $^{2 \dagger}$, Jane Skinner ${ }^{1}$, Caroline L Relton ${ }^{3}$

\begin{abstract}
Background: Genetic variation in folate metabolism has been associated with survival in utero, the success of in vitro fertilisation, multiple pathologies and longevity.

Methods: We have looked at the prevalence of genetic variants of the enzymes MTHFR and TYMS in 2,898 DNA samples derived from five cohorts collected in the United Kingdom. The simultaneous analysis of genetic variants of the MTHFR and TYMS loci was carried out to investigate a putative gene-gene interaction that was first observed in an elderly male population from Norfolk.
\end{abstract}

Results: We have made a consistent observation in five population cohorts; the proportion of individuals who are homozygous for the $2 \mathrm{R}$ allele of the $5^{\prime} U T R$ TYMS polymorphism is less in individuals who are homozygous for the T allele of MTHFR 677 than in individuals homozygous for the C allele of MTHFR 677 ( $p=0.02$ ).

Conclusions: These data may suggest a gene-gene interaction and could be evidence of genetic selection, with some pregnancies more or less viable as a consequence of genetic variation. If these genetic phenomena affect the way folate is handled at the cellular level in utero it is possible that maternal folic acid intake may over-ride such genetic selection.

\section{Background}

Folate-dependent one-carbon metabolism is essential for nucleotide synthesis, methionine synthesis and for DNA methylation and depends on a number of enzymes that are functionally polymorphic. SNPs and other polymorphisms of the genes MTHFR, MTRR and TYMS have been associated with cardiovascular disease, neural tube defects, Down syndrome and leukaemia [1-4]. Adequate dietary folate, and its efficient metabolism have well-established roles in disease prevention; deficiency is associated with increased risk of neural tube defects, vascular disease, cancer and anaemia [5].

Proposals for the mandatory fortification of flour with folate in the United Kingdom are driven by the importance of this B vitamin to the development of the early embryo [6]. Embryo development and viability has been the subject of many epidemiological studies of genetic variants, including, and possibly predominantly, in those genes involved in folate metabolism [2-4,7]. B-vitamin

\footnotetext{
*Correspondence: b.jennings@uea.ac.uk

† Contributed equally

${ }^{1}$ School of Medicine, Health Policy and Practice, University of East Anglia,
} Norwich NR4 7TJ, UK status and folate metabolism have been shown to influence the outcome of in vitro fertilisation (IVF) $[8,9]$. Women who are homozygous for a variant of the gene MTHFR $(1298 \mathrm{~A}>\mathrm{C})$ were less likely to produce a livebirth than other women undergoing IVF and the chances of a twin birth increased with plasma and red cell folate concentrations [8]. The authors proposed that the woman's genotype is linked to her potential to produce good quality embryos and that this, coupled with folate status, increases the likelihood of IVF resulting in live births. Haggarty et al also observed an association between raised concentrations of homocysteine and an increase in the risk of miscarriage in their study of women undergoing IVF and elevated homocysteine levels has been linked recurrent pregnancy loss previously [10].

A meta-analysis has demonstrated that maternal hyperhomocysteinaemia (a metabolic consequence of low folate status) is associated with orofacial cleft and congenital heart defects [11], but the authors found no independent association between these congenital malformations and MTHFR genotype in either the mothers or children. However, the negative in utero effect of 
raised homocysteine has been proposed by Lucock and Yates as one of the mechanisms by which the genetic variant, MTHFR $677 \mathrm{C}>\mathrm{T}$, compromises the viability of a pregnancy when dietary folate levels are inadequate [12]. These authors also hypothesise that when folate levels are unrestricted, there is a survival advantage in utero for homozygotes for the $677 \mathrm{C}>\mathrm{T}$ allele because that genotype will increase the levels of 5,10 methylene tetrahydrofolate favouring DNA synthesis and stability. This hypothesis is supported by the authors of a recent study of the prevalence of this genotype in adult populations and in DNA samples taken from spontaneous abortions, they present evidence for the selection of the $677 \mathrm{C}>\mathrm{T}$ allele associated with increased folate intake by women in the peri-conceptional period [13].

The MTHFR $677 \mathrm{C}>\mathrm{T}$ variant is associated with raised homocysteine concentrations and lower enzyme concentrations [14]. Association studies of the MTHFR $677 \mathrm{C}>\mathrm{T}$ variant and adverse pregnancy outcomes have in the main concluded that this variant is important in the pathogenesis of adverse pregnancy outcomes [15]. Less compelling evidence is available for TYMS genetic variants [16], one of which is a 5'UTR repeat variant $(2 R / 3 R)$ and the rare $2 R$ variant is associated with lower TYMS expression and plasma homocysteine [17]. The simultaneous analysis of multiple genetic variants allows the consideration of additive, synergistic and compensating variants of folate metabolism. Disease association studies of two or more enzyme variants of folate metabolism are few, but suggest the possibility of gene-gene interactions or epistasis. One study has demonstrated a multiplicative effect on phenotype for the MTHFR $677 \mathrm{C}>\mathrm{T}$ and MTRR 66G $>\mathrm{A}$ genotype combinations in relation to Down syndrome [4]. Another study demonstrated that three genotype combinations of the loci MTRR/FOLH1; MTHFR 677/ $C B S$ and MTHFR 677/MTRR increase the risk of neural tube defects [7].

A functional study of MTHFR and TYMS has shown that these enzymes compete for limiting supplies of folate required for homocysteine methylation [17]; which illustrates the likelihood that certain steps in onecarbon metabolism present bottlenecks for the distribution of folate species, and enzyme variants in these steps may be important.

We and others have previously found evidence for depletion of individuals homozygous for MTHFR $677 \mathrm{C}>\mathrm{T}$ relative to younger cohorts, and postulated it to be due to genotype-specific survival [18-20]. Because of observations made in cross-sectional population studies to explore the impact of genetic variants of the enzymes MTHFR and TYMS on survival in elderly cohorts, we have studied the prevalence of two polymorphisms in younger populations. The MTHFR and TYMS loci are found on chromosomes 1 and 18 respectively so linkage disequilibrium will not explain any digenic phenomena observed.

\section{Methods}

\section{Subjects}

The polymorphic locus MTHFR $677 \mathrm{C}>\mathrm{T}$ and the 5 'UTR repeat variant of TYMS (2R/3R) were co-analysed in 2,898 DNA samples from the following 5 population cohorts.

\section{Cohort 1}

DNA extracted from 1178 blood samples collected from an elderly male population undergoing full blood counts in primary care or as patients at the Norfolk and Norwich University Hospital. Mean age $=84$ years [range 70-99 years].

\section{Cohort 2}

DNA extracted from 438 blood samples collected from an elderly female population undergoing full blood counts in primary care or as patients at the Norfolk and Norwich University Hospital. Mean age $=92$ years [range 89-104 years].

\section{Cohort 3}

DNA was extracted from 409 blood samples collected from a young female population undergoing full blood counts in primary care or as patients at the Norfolk and Norwich University Hospital. Mean age $=27$ years [range 18-40 years].

\section{Cohort 4}

DNA was analysed from 398 blood samples from apparently healthy male volunteers recruited through a local community media-advertising campaign for a genetic and iron homeostasis study [21]. Mean age $=60$ years [range 40-80 years]. The MTHFR data from this cohort has been described previously [22].

\section{Cohort 5}

DNA was obtained from 475 female volunteers from North Cumbria Community Genetics Project (NCCGP) [23]. Mean age of whole NCCGP cohort $=28$ years [range 16-44 years].

\section{Genotyping}

\section{DNA extraction and genotyping}

High molecular weight DNA was sub-aliquoted onto 96 well plates at a concentration of approximately $100 \mathrm{ng} /$ $\mu \mathrm{l}$. All subsequent reactions were also performed in 96 well plates. The PCR reactions comprised of $100 \mathrm{ng}$ DNA, $200 \mathrm{nmol} / \mathrm{L}$ of each primer and $1 \times$ PCR Thermo Start Mastermix (ABgene UK, Epsom, England) in a 25 $\mu \mathrm{l}$ volume. The PCR conditions for each assay are shown in table 1.

The MTHFR assay required restriction digestion prior to gel electrophoresis. $10 \mu \mathrm{l}$ of PCR product was digested overnight at $37^{\circ} \mathrm{Cina} 20 \mu \mathrm{l}$ reaction volume. The enzyme and buffer used (New England Biolabs, Hitchin, UK) are described in table 1. 
Table 1 Description of PCR Assays

\begin{tabular}{|c|c|c|}
\hline $\begin{array}{l}\text { GENE } \\
\text { SNP I.D. or description }\end{array}$ & $\begin{array}{l}\text { MTHFR } \\
\text { rs1801133 }\end{array}$ & $\begin{array}{l}\text { TYMS } \\
\text { 5'UTR } \\
\text { EX1+52CCGCGCCACTTC } \\
\text { GCTGCCTCCGTCCCC }\end{array}$ \\
\hline $\begin{array}{l}\text { Rare allelic form } \\
\text { (amino acid changes) }\end{array}$ & $677 C>T(A 222 V)$ & $\begin{array}{l}2 R \\
{[17]}\end{array}$ \\
\hline Sense primer and antisense primer & $\begin{array}{l}\text { GGGTCAGAAGCATATCAGTCATG } \\
\text { CACAAAGCGGAAGAATGTGTC }\end{array}$ & $\begin{array}{l}\text { AAAAGGCGCGCGGAAG } \\
\text { GCCGGCCACAGGCAT }\end{array}$ \\
\hline Annealing temperature, cycle number & $55^{\circ} \mathrm{C}, 38$ cycles & $61^{\circ} \mathrm{C}, 38$ cycles \\
\hline PCR product size in base pairs & 326 & 111 or 139 \\
\hline Restriction enzyme (number of units) or size of ins/del & Hinf I (0.2), buffer 2 & 28 bp repeat visible by gel electrophoresis \\
\hline $\begin{array}{l}\text { Fragment sizes for common allele in base pairs. } \\
\text { Fragment sizes for rare allele in base pairs. }\end{array}$ & $\begin{array}{l}104 \text { and } 222 \\
102,166 \text { and } 53\end{array}$ & $\begin{array}{l}139 \\
111\end{array}$ \\
\hline
\end{tabular}

The PCR products were electrophoresed on a $1 \times$ Tris/Borate/EDTA, 3\% Metaphor agarose (FMC Bioproducts, Lichfield, UK) gel in a stretch-wide apparatus (ABgene, Epsom, UK) at $80 \mathrm{~V}$ for 50 minutes.

\section{Quality assurance}

Gel analysis data were screened independently by two scientists (GW, BJ) and approximately $10 \%$ of the samples were genotyped a second time to check for concordance. A duplication of the MTHFR genotyping for 264 samples showed $100 \%$ concordance. A duplication of the TYMS genotyping for 362 samples showed $99.2 \%$ concordance and resulted in 3 reassigned genotypes. Furthermore, 4 samples that carried the rare 4 repeat allele were excluded from the analysis. The overall success rate for genotyping (in primary genotyping and re-analyses) was $99.6 \%$ for the MTHFR locus and $97.2 \%$ for the TYMS locus.

The samples from cohorts 1 to 4 were also genotyped for MTHFR 1298 (rs1801131) and found to be in complete linkage disequilibrium with MTHFR 677 as expected.

\section{Statistics}

Hardy-Weinberg equilibrium (HWE); The $\chi^{2}$-test was used to analyse the frequencies of genotypes detected for each locus and relative fitness ratios were estimated for homozygotes compared to heterozygotes.

We tested the hypothesis that the proportion of individuals homozygous for the $2 \mathrm{R}$ allele of the 5'UTR $T Y M S$ polymorphism was lower in the group homozygous for the T allele of MTHFR 677 than in the group homozygous for the C allele of MTHFR 677 using a one-sided Fisher's exact test for each population. We used Stouffer's consensus combined P-value test, as described and recommended in Rice (1990), which is designed to combine the P-values from a set of independent tests addressing the same hypothesis [24].

\section{Ethics}

Ethical approval for the study of anonymised DNA samples of groups 1 to 4 was obtained from Norwich and
Waveney LREC. Ethical approval for the study of group 5 was obtained from Leeds West MREC.

\section{Results \\ Genotyping}

We have simultaneously determined the MTHFR 677 and TYMS 5'UTR genotype frequencies using DNA samples from 5 population cohorts comprising 2,898 individuals. The prevalence data and deviations from HWE are described in table 2 in addition to the relative fitness ratios for homozygotes compared to heterozygotes. Data are only presented for those samples that were successfully genotyped at both loci and which carried either the $2 \mathrm{R}$ or $3 \mathrm{R}$ allele at the TYMS locus.

We observed that the proportion of individuals who are homozygous for the TYMS $2 \mathrm{R}$ allele is different in the two groups of homozygotes for the MTHFR 677; the proportion of individuals who are homozygous for the $2 \mathrm{R}$ allele of the 5'UTR TYMS polymorphism in individuals with the $\mathrm{C}>\mathrm{T}$ allele of MTHFR 677 is less than the proportion of individuals who are homozygous for the $2 \mathrm{R}$ allele in homozygotes for the C allele of MTHFR 677 (see figure 1). We first made this observation in the elderly Norfolk cohorts 1 and 2. Therefore, to test if this observation was a real phenomenon, we analysed the MTHFR and TYMS genotypes in new populations and subsequently made the same observation in Norfolk cohorts 3 and 4 and in cohort 5 , the female volunteers from North Cumbria Community Genetics Project [23]. The observations were consistent in all populations studied.

\section{Statistics}

We found for all populations tested that the proportion of individuals who are homozygous for the TYMS $2 \mathrm{R}$ allele was lower in the TT homozygotes for MTHFR 677 than the CC homozygotes, but the individual tests were not significant (Table 3). The consensus combined $\mathrm{p}$-value test [23] was significant $(\mathrm{p}=0.02)$. Removing 
Table 2 The MTHFR and TYMS genotype distributions, relative fitnesses and deviations from HWE of the genotypes in the 5 populations from Norfolk and Cumbria

\begin{tabular}{|c|c|c|c|c|c|c|c|}
\hline MTHFR & & $C C$ & $C T$ & $\pi T$ & $\begin{array}{l}\text { Relative fitness } \\
\text { CC vs CT }\end{array}$ & $\begin{array}{c}\text { Relative fitness } \\
T T \text { vs } C T\end{array}$ & Deviation from $H W E$ \\
\hline \multirow[t]{2}{*}{ Cohort 1} & Observed & 486.0 & 564.0 & 128.0 & 0.92 & 0.85 & 0.063 \\
\hline & Expected & 500.7 & 534.6 & 142.7 & & & \\
\hline \multirow[t]{2}{*}{ Cohort 2} & Observed & 206.0 & 191.0 & 41.0 & 0.98 & 0.95 & 0.824 \\
\hline & Expected & 207.5 & 187.9 & 42.5 & & & \\
\hline \multirow[t]{2}{*}{ Cohort 3} & Observed & 179.0 & 178.0 & 52.0 & 1.06 & 1.11 & 0.445 \\
\hline & Expected & 175.6 & 184.8 & 48.6 & & & \\
\hline \multirow[t]{2}{*}{ Cohort 4} & Observed & 166.0 & 202.0 & 30.0 & 0.81 & 0.61 & 0.003 \\
\hline & Expected & 179.1 & 175.8 & 43.1 & & & \\
\hline \multirow[t]{2}{*}{ Cohort 5} & Observed & 185.0 & 214.0 & 76.0 & 1.08 & 1.13 & 0.287 \\
\hline & Expected & 179.5 & 225.0 & 70.5 & & & \\
\hline$\overline{T Y M S}$ & & 3 & $2 \_3$ & $2 \_2$ & $\begin{array}{c}\text { Relative fitness } \\
3 \_3 \text { vs 3_2 }\end{array}$ & $\begin{array}{c}\text { Relative fitness } \\
2 \_2 \text { vs 3_2 }\end{array}$ & Deviation from $\mathrm{HWE}$ \\
\hline \multirow[t]{2}{*}{ Cohort 1} & Observed & 350.0 & 541.0 & 287.0 & 1.16 & 1.18 & 0.007 \\
\hline & Expected & 326.8 & 587.3 & 263.8 & & & \\
\hline \multirow[t]{2}{*}{ Cohort 2} & Observed & 126.0 & 216.0 & 96.0 & 1.02 & 1.01 & 0.848 \\
\hline & Expected & 125.0 & 218.0 & 95.0 & & & \\
\hline \multirow[t]{2}{*}{ Cohort 3} & Observed & 129.0 & 180.0 & 100.0 & 1.24 & 1.28 & 0.022 \\
\hline & Expected & 117.3 & 203.5 & 88.3 & & & \\
\hline \multirow[t]{2}{*}{ Cohort 4} & Observed & 124.0 & 184.0 & 90.0 & 1.14 & 1.16 & 0.189 \\
\hline & Expected & 117.2 & 197.6 & 83.2 & & & \\
\hline \multirow[t]{2}{*}{ Cohort 5} & Observed & 146.0 & 240.0 & 89.0 & 0.96 & 0.94 & 0.641 \\
\hline & Expected & 149.0 & 234.1 & 92.0 & & & \\
\hline
\end{tabular}

Observed and expected genotype frequencies and deviations from HWE were calculated from the prevalence data for the MTHFR 677 and TYMS 5 'UTR loci in 2898 samples that were simultaneously genotyped at both loci

the hypothesis-generating cohorts 1 and 2 from the analysis, the consensus $\mathrm{p}$-value was still significant $(\mathrm{p}=$ 0.04 ) for cohorts 3,4 and 5 only.

\section{Discussion}

We have observed a consistent gene-gene interaction in 5 different cohorts. Certain genotypes are differentially represented in these populations and this could be evidence of genetic selection during early development; in

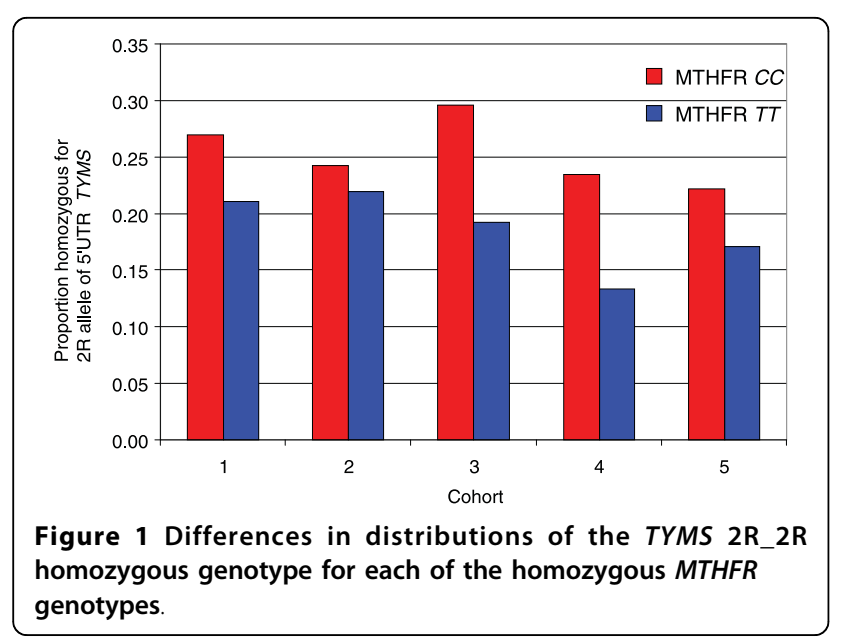

gamete formation or in utero, with some gametes or pregnancies more or less viable because of variation in the way folate is handled at the cellular level, the metabolism of folate being the link between these enzymes and their genetic loci.

There is published evidence for significant genomewide transmission distortion [25] which could be caused by genetic and/or environmental influences on gamete selection and embryo viability. Ebisch et al demonstrated that sperm concentration can be raised with folic acid and zinc sulphate supplementation, but only in males who are homozygous for the $677 \mathrm{C}$ genotype [26]. Lucock and Yates have hypothesised that when folate levels are unrestricted, there is a survival advantage in utero for homozygotes for the $677 \mathrm{C}>\mathrm{T}$ allele because that genotype will increase the levels of 5,10 methylene tetrahydrofolate favouring DNA synthesis and stability [12]. The investigations by Mayor-Olea et al found that the wild type, $677 \mathrm{CC}$, genotype is almost absent in spontaneous abortions suggesting that this genotype may protect against pregnancy loss. However, they also interpret the increase in the prevalence of the $\mathrm{T}$ allele alongside the use of peri-conceptional folic acid as an indication that an environmental factor can lead to the 
Table 3 Distribution of TYMS homozygote status for MTHFR homozygotes

\begin{tabular}{|c|c|c|c|c|c|c|c|c|c|c|}
\hline \multirow[b]{3}{*}{ MTHFR } & \multicolumn{10}{|c|}{ TYMS } \\
\hline & \multicolumn{2}{|c|}{ Cohort 1} & \multicolumn{2}{|c|}{ Cohort 2} & \multicolumn{2}{|c|}{ Cohort 3} & \multicolumn{2}{|c|}{ Cohort 4} & \multicolumn{2}{|c|}{ Cohort 5} \\
\hline & 2 & Other & 222 & Other & $2 \_2$ & Other & $2 \_2$ & Other & 2 & Other \\
\hline CC & 131 & 355 & 50 & 156 & 53 & 126 & 39 & 127 & 41 & 144 \\
\hline$\pi$ & 27 & 101 & 9 & 32 & 10 & 42 & 4 & 26 & 13 & 63 \\
\hline$\overline{p^{*}}$ & & 0.11 & & 0.46 & & 0.09 & & 0.16 & & 0.23 \\
\hline \multicolumn{11}{|c|}{ Consensus $P^{\dagger} 0.02$ (all cohorts), 0.04 (cohorts 3, 4 and 5 only) } \\
\hline
\end{tabular}

genetic selection for the $\mathrm{T}$ allele or permit the survival of deleterious genotypes [13].

Our observation could not be caused by any simple genotyping error because the relationship observed between MTHFR and TYMS is independent of heterogeneity in the allele frequencies for the individual polymorphisms between the cohorts. During the course of these experiments we investigated the possibility of technical artefacts because it can be seen from table 2 that some of the individual gene frequencies were out of HWE (see MTHFR frequency for cohort 4 and TYMS frequencies for cohorts 1 and 3) and genotyping errors could explain this. Undigested PCR product in the analysis of the MTHFR 677 polymorphism, and preferential amplification of the TYMS allele with 2 rather than 3 repeats could produce erroneous data for the individual genotypes. Although only a single laboratory assay was used for each genotype analysis, the DNA quality and data interpretation checks described in the methods provide confidence in the reproducibility of our methods. Futhermore, while genotyping errors could result in perturbation of HWE they would not generate the significant co-segregation of MTHFR and TYMS genotypes described.

Deviation from HWE is also possible if there are selective advantages for particular genotypes. A selective advantage for particular MTHFR genotypes could lead to deviations from HWE in the general population; heterozygote advantage occurs when environmental situations lead to heterozygous individuals for some disease alleles having increased fitness over both homozygous genotypes. In the older cohorts $(1,2$ and 4$)$ in this study both homozygous groups showed a reduced fitness relative to the heterozygotes for MTHFR 677 (see table 2). We and others have previously found evidence for depletion of individuals homozygous for the MTHFR $677 \mathrm{C}>\mathrm{T}$ relative to younger cohorts, and postulated it to be due to genotype-specific fatal disease [18-20,24]. However, given that the interaction between MTHFR and TYMS is found in all age groups, this interaction cannot be interpreted as an age-related survival factor; i. e. the death of some individuals from genotype-specific fatal disease does not explain the observation.
Given that all of the subjects from our study were born before the influence of folate related public health initiatives, could B-vitamin supplementation affect the biological phenomena that we and others have described? Haggarty et al report that folic acid intervention has not resulted in genetic selection in favour of the MTHFR 677T allele [27], however this does not take into account potential gene-gene interactions at other folate-related loci and does not discount the possibility that numerous genetic variants may act in concert to exert selective pressure.

\section{Conclusions}

Our data may suggest a gene-gene interaction and could be evidence of genetic selection, with some pregnancies more or less viable as a consequence of genetic variation. If these genetic phenomena affect the way folate is handled at the cellular level in utero it is possible that maternal folic acid intake may over-ride such genetic selection. Our findings should now be tested in independent population cohorts.

\section{Abbreviations \\ HUGO: approved nomenclature used for the gene loci; CBS: cystathionine- beta-synthase; FOLH1: folate hydrolase (prostate-specific membrane antigen) 1; MTHFR: 5,10-methylenetetrahydrofolate reductase (NADPH); MTRR: methyltetrahydrofolate-homocysteine methyltransferase reductase; TYMS: thymidylate synthetase; HWE: Hardy-Weinberg Equilibrium.}

\section{Acknowledgements}

The funding for this study came from the University of East Anglia. Della Heron carried out most of the DNA extractions and gave technical assistance.

\section{Author details}

${ }^{1}$ School of Medicine, Health Policy and Practice, University of East Anglia, Norwich NR4 7TJ, UK. ${ }^{2}$ Department of Molecular Genetics, Norfolk and Norwich University Hospital, Norwich NR4 7UY, UK. ${ }^{3}$ Institute for Ageing and Health and Human Nutrition Research Centre, Newcastle University, Royal Victoria Infirmary, Newcastle upon Tyne, NE1 4LP, UK.

\section{Authors' contributions}

GW, BJ and CR participated in the design of the study and contributed to the drafting or preparation of the manuscript. GW designed and optimised most of the PCR assays, collected and analysed most of the data. BJ also analysed the PCR data. CR also analysed the genotyping data by HWE. JS advised on and completed the statistical analyses. All authors contributed to and approved the final manuscript. 


\section{Competing interests}

The authors declare that they have no competing interests.

Received: 2 June 2009

Accepted: 1 February 2010 Published: 1 February 2010

\section{References}

1. Wald DS, Law M, Morris JK: Homocysteine and cardiovascular disease: evidence on causality from a meta-analysis. Bmj 2002, 325(7374):1202.

2. Kirke PN, Mills JL, Molloy AM, Brody LC, O'Leary VB, Daly L, Murray S, Conley M, Mayne PD, Smith O, et al: Impact of the MTHFR C677T polymorphism on risk of neural tube defects: case-control study. $B m$ j 2004, 328(7455):1535-1536.

3. Shields DC, Kirke PN, Mills JL, Ramsbottom D, Molloy AM, Burke H, Weir DG, Scott JM, Whitehead AS: The "thermolabile" variant of methylenetetrahydrofolate reductase and neural tube defects: An evaluation of genetic risk and the relative importance of the genotypes of the embryo and the mother. Am J Hum Genet 1999, 64(4):1045-1055.

4. Hobbs CA, Sherman SL, Yi P, Hopkins SE, Torfs CP, Hine RJ, Pogribna M, Rozen $\mathrm{R}$, James $\mathrm{S}$ : Polymorphisms in genes involved in folate metabolism as maternal risk factors for Down syndrome. Am J Hum Genet 2000, 67(3):623-630.

5. Lucock M: Is folic acid the ultimate functional food component for disease prevention?. Bmj 2004, 328(7433):211-214.

6. Department of Health: Report on health social subjects. 50 . Folic acid and the prevention of disease. Report of the Committee on Medical Aspects of Food and Nutrition Policy. London: The Stationary Office 2000.

7. Relton CL, Wilding CS, Pearce MS, Laffling AJ, Jonas PA, Lynch SA, Tawn EJ, Burn J: Gene-gene interaction in folate-related genes and risk of neural tube defects in a UK population. J Med Genet 2004, 41(4):256-260

8. Haggarty P, McCallum $H$, McBain $H$, Andrews $K$, Duthie $S$, McNeill $G$, Templeton A, Haites N, Campbell D, Bhattacharya S: Effect of B vitamins and genetics on success of in-vitro fertilisation: prospective cohort study. Lancet 2006, 367(9521):1513-1519.

9. Boxmeer JC, Macklon NS, Lindemans J, Beckers NG, Eijkemans MJ, Laven JS, Steegers EA, Steegers-Theunissen RP: IVF outcomes are associated with biomarkers of the homocysteine pathway in monofollicular fluid. Hum Reprod 2009, 24(5):1059-1066.

10. Nelen WL, Blom HJ, Steegers EA, den Heijer M, Eskes TK: Hyperhomocysteinemia and recurrent early pregnancy loss: a metaanalysis. Fertil Steril 2000, 74(6):1196-1199.

11. Verkleij-Hagoort A, Bliek J, Sayed-Tabatabaei F, Ursem N, Steegers E, Steegers-Theunissen R: Hyperhomocysteinemia and MTHFR polymorphisms in association with orofacial clefts and congenital heart defects: a meta-analysis. Am J Med Genet A 2007, 143A(9):952-960.

12. Lucock M, Yates Z: Folic acid - vitamin and panacea or genetic time bomb?. Nat Rev Genet 2005, 6(3):235-240.

13. Mayor-Olea A, Callejon G, Palomares AR, Jimenez AJ, Gaitan MJ, Rodriguez A, Ruiz M, Reyes-Engel A: Human genetic selection on the MTHFR 677C>T polymorphism. BMC Med Genet 2008, 9(1):104.

14. Bailey LB, Gregory JF: Polymorphisms of methylenetetrahydrofolate reductase and other enzymes: metabolic significance, risks and impact on folate requirement. J Nutr 1999, 129(5):919-922.

15. Botto LD, Yang Q: 5,10-Methylenetetrahydrofolate reductase gene variants and congenital anomalies: a HuGE review. Am J Epidemiol 2000, 151(9):862-877.

16. Wilding CS, Relton CL, Sutton MJ, Jonas PA, Lynch SA, Tawn EJ, Burn J: Thymidylate synthase repeat polymorphisms and risk of neural tube defects in a population from the northern United Kingdom. Birth Defects Res A Clin Mol Teratol 2004, 70(7):483-485.

17. Trinh BN, Ong CN, Coetzee GA, Yu MC, Laird PW: Thymidylate synthase: a novel genetic determinant of plasma homocysteine and folate levels. Hum Genet 2002, 111(3):299-302.

18. Heijmans BT, Gussekloo J, Kluft C, Droog S, Lagaay AM, Knook DL, Westendorp RG, Slagboom EP: Mortality risk in men is associated with a common mutation in the methylene-tetrahydrofolate reductase gene (MTHFR). Eur J Hum Genet 1999, 7(2):197-204.

19. Faure-Delanef $L$, Quere I, Chasse JF, Guerassimenko O, Lesaulnier $M$, Bellet H, Zittoun J, Kamoun P, Cohen D: Methylenetetrahydrofolate reductase thermolabile variant and human longevity. Am J Hum Genet 1997, 60(4):999-1001.

20. Jennings BA, Wimperis JZ, Tickner T, Naidu R, Willis G: MTHFR 677 polymorphism in an elderly patient cohort. European Journal of Human Genetics 2003, 11:S249.

21. Roe MA, Heath AL, Oyston SL, Macrow C, Hoogewerff JA, Foxall R, Dainty JR, Majsak-Newman G, Willis G, Fairweather-Tait SJ: Iron absorption in male C282Y heterozygotes. Am J Clin Nutr 2005, 81(4):814-821.

22. Khandanpour N, Willis G, Meyer FJ, Armon MP, Loke YK, Wright AJ, Finglas PM, Jennings BA: Peripheral arterial disease and methylenetetrahydrofolate reductase (MTHFR) C677T mutations: A casecontrol study and meta-analysis. J Vasc Surg 2009, 49(3):711-718.

23. Chase DS, Tawn EJ, Parker L, Jonas P, Parker CO, Burn J: The North Cumbria Community Genetics Project. J Med Genet 1998, 35(5):413-416.

24. Rice WR: A Consensus Combined P-Value Test and the Family-Wide Significance of Component Tests. Biometrics 1990, 46(2):303-308,

25. Zollner S, Wen X, Hanchard NA, Herbert MA, Ober C, Pritchard JK: Evidence for extensive transmission distortion in the human genome. Am J Hum Genet 2004, 74(1):62-72.

26. Ebisch IM, van Heerde WL, Thomas CM, Put van der N, Wong WY, SteegersTheunissen RP: C677T methylenetetrahydrofolate reductase polymorphism interferes with the effects of folic acid and zinc sulfate on sperm concentration. Fertil Steril 2003, 80(5):1190-1194.

27. Haggarty P, Campbell DM, Duthie S, Andrews K, Hoad G, Piyathilake C, Fraser I, McNeill G: Folic acid use in pregnancy and embryo selection. Bjog 2008, 115(7):851-856.

\section{Pre-publication history}

The pre-publication history for this paper can be accessed here:http://www. biomedcentral.com/1471-2350/11/18/prepub

doi:10.1186/1471-2350-11-18

Cite this article as: Jennings et al:: Genetic selection? A study of individual variation in the enzymes of folate metabolism. BMC Medical Genetics 2010 11:18.

\section{Submit your next manuscript to BioMed Central and take full advantage of:}

- Convenient online submission

- Thorough peer review

- No space constraints or color figure charges

- Immediate publication on acceptance

- Inclusion in PubMed, CAS, Scopus and Google Scholar

- Research which is freely available for redistribution

Submit your manuscript at www.biomedcentral.com/submit
C Biomed Central 